\title{
The Role of Performance Measurement SYSTEMS ON GLOBALIZED MARKETS
}

\author{
BILAS, V. \& FRANC, S.
}

Abstract: There is a continuous evolution of performance measurement systems as a result of changing market and business conditions. Without the use of modern intelligent systems of controlling and accounting it is almost impossible to successfully perform on the global market. The aim of the paper is to give a short literature review of the performance measurement systems evolution and to highlight their advantages and disadvantages. A comparison of the selected performance measurement systems is given and potential challenges of the future systems development are analyzed.

Key words: globalization, performance measures, balanced scorecard, intelligent systems
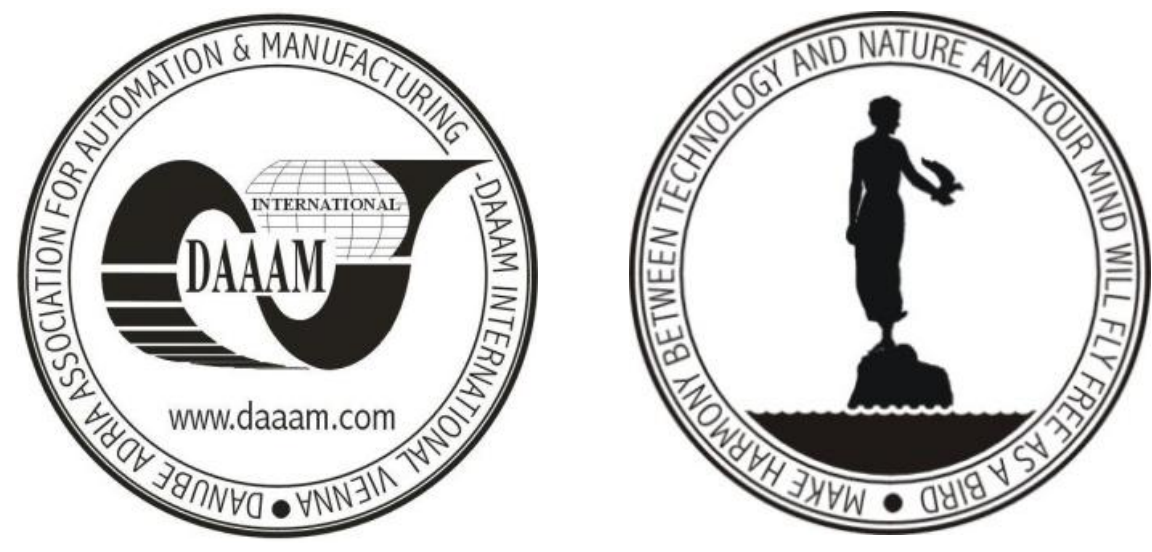

Authors' data: Ph.D., Univ.spec.oec. Bilas, V[latka]; Franc, S[anja], University of Zagreb, Faculty of Economics and Business, J.F. Kennedy Sq.6, 10000 Zagreb, Croatia, vbilas@efzg.hr, sfranc@efzg.hr

This Publication has to be referred as: Bilas, V[latka] \& Franc, S[anja] (2010). The Role of Performance Measurement Systems on Globalized Markets, Chapter 30 in DAAAM International Scientific Book 2010, pp. 313-320, B.Katalincic (Ed.), Published by DAAAM International, ISBN 978-3-901509-74-2, ISSN 1726-9687, Vienna, Austria

DOI: $10.2507 /$ daaam.scibook.2010.30 
Bilas, V. \& Franc, S.: The Role of Performance Measurement Systems on Globaliz...

\section{Introduction}

Performance measurement and management (PMM) is a balanced and dynamic system that enables support of decision making processes by gathering, elaborating and analyzing information (Neely, Adams, Kennerly, 2002).

In the era of globalization, knowledge and information are significant factors of business success. Firms have to be flexible and capable to cope with uncertain market conditions and fierce competition by creating suitable business strategies. In order to do so, they need to be aware of their business situation, i.e. their business performance. Without the use of modern intelligent systems of controlling and accounting it is almost impossible to successfully perform on global markets. There are numerous measures that a firm can use in order to assess its' business situation, and all of those measures are used to create and facilitate action to improve the performance.

The aim of this paper is to give a short literature review of the performance measurement systems evolution and to highlight their advantages and disadvantages. A comparison of selected performance measurement systems is given and potential challenges of the future systems development are analyzed. This paper is an introduction to a planned future research on the development of new performance measurement systems.

Limitations of the analysis are limited statistical data sources about the level of development and implementation of the performance measurement models.

The paper is divided into five parts. The first part is the introduction. In the second part, a short description of the performance measurement models evolution is described. In the following section a comparison of different performance measurement management systems and their outputs is given. In the fourth section, challenges of the future development of the performance measurement and management systems are described, and the last part is the conclusion.

\section{Background and literature review}

The process of globalization has resulted in continuously changing business environment. Globalized markets and strong competition makes it necessary for firms to make continuous improvements, monitor and understand their performance. Consequently, information about business performance is extremely valuable.

While different performance measurement models use different indicators, the unique rule is that the ones used must be meaningful, transparent and understandable.

Furthermore, increased focus on improvement and significant developments in information and communication technologies (ICT) are the most important trends that have created a need, as well as a favorable context for the implementation of performance measurement models. Until recently, many firms have delegated management of the software development process to their technical staff without proper management training. Growing competition, as well as shorter time-to-market made it necessary for management to take control of this component which became critical to their business success (Buglione \& Abram, 2000). Advancements in the 
ICT area made it possible for firms to develop and implement modern intelligent systems of controlling and accounting that help monitor business performance.

In the past, traditional measures of performance were used. What is more, until the 1980s, financial indicators were most commonly used to evaluate firms' performance.

However, in light of the fast spreading globalization process and changed business environment those measures were proven to be limited indicators of performance. Traditional measures based on cost accounting information were recognized as inadequate to explain the performance and improvements seen by the customer.

Since the middle of 1980s firms emphasized the growing need of controlling their production and business processes. Non-financial measures, such as the quality of products or services, customer satisfaction, delivery time, etc., have gained on importance, and in combination with different financial measures give best results in measuring and monitoring information on overall performance.

Although there are a number of reasons why firms use non-financial performance measures, the primary reason is that some of them are leading indicators of financial performance (Kaplan and Norton 1992; 2001).Understanding the link between financial information and non-financial information and integrating them into an information system is a major challenge for businesses today (Lebas, 1994).

\section{A Comparison of the selected performance measurement and management systems (PMMS)}

A performance measurement system enables a firm to plan, measure and control performance according to a predefined strategy (Johnson, 2007).

There is a continuous evolution of performance measurement systems accordingly to the changing environment and business conditions. The major performance measurement and management systems in use today are: Activity-based Costing and Management; Economic Value Added; Balanced Scorecard; Quality management; Customer Value Analysis and Performance Prism.

In continuation, mentioned systems will be described.

\subsection{Activity-based Management (ABM) and Economic Value Added (EVA)}

The ABM and EVA are traditional systems developed in the 1980s that rely mostly on cost-accounting and other financial information. They came as a result of observed deficiencies in the traditional, purely accounting systems.

Activity-based Management (ABM) is a discipline that focuses on the management of activities to maximize the profit from each activity and to improve the value forcustomers (Johnson, 2007). ABM was firstly used only in manufacturing firms, but with time, its use spread to other industries, service firms, government agencies, etc. Activity-based costing (ABC) is not a method of costing, but a technique for managing the organization better. The approach was developed to provide better insight into how overhead costs should be allocated to individual customer or product and it enables a firm to distinguish between profitable and profitless activities. 
Economic Value Added (EVA) is a financial performance measure that is most directly connected to the creation of shareholder value over time. Using EVA technique, managers can get better information necessary to make decisions that will create greatest shareholders wealth. Since it is a purely financial model, EVA does not serve for articulating a strategy of a firm. It is often combined with other measures like the BSC.

\subsection{The Balanced Scorecard}

The Balanced Scorecard (BSC) is one of the most commonly used performance measure model today. It was originally created as a performance measurement system in 1992 by dr. Robert Kaplan and dr. David Norton at the Harvard Business School. The BSC represents a new framework for the integration of financial and non-financial performance measures. Through the use of various perspectives, the BSC captures both leading and lagging performance measures, thereby providing a balanced view of firms' performance (Johnson, 2007).

The methodology examines the performance in four areas: (1) financial analysis that includes operating costs and return on investments, (2) customer analysis which looks at customer satisfaction and retention, (3) internal analysis which looks at production and innovation, and finally (4) learning and growth analysis which explores the effectiveness of management.

The benefits from properly implemented BSC system include: making strategic improvements a continuous process, simplifying firms' strategy by translating it into more easily understood operational metrics and goals.

\subsection{Quality Management}

Over the past few decades various types of quality programs such as Total Quality Management, European Foundation Quality Management (EFQM), the Balbridge National Quality Program, etc. have been developed and adopted by firms. The major focus of all of the mentioned programs is business performance measurement.

For example, the EFQM is a framework based on 9 criteria. The first five are classified as "enablers" and the last four are the "results". The "enabler" criteria cover what a firm does, and the "result" criteria measure what a firm achieves. The model is based on the premise that excellent results with respect to the performance, customers, people and society are achieved through leadership, driving policy and strategy, that are delivered through people, partnerships, resources and processes.

The Balbridge National Quality program, as opposed to the EFQM, measures performance in seven categories, namely (1) leadership, (2) human resources focus, (3) strategic planning, (4) process management, (5) customer and market focus, (6) information and analytics, (7) business results.

Quality programs are useful in order to determine how to improve a firms' performance, but they are less useful for measuring relative performance among different firms in different industries.

When comparing the BSC and Quality programs some differences can be noticed, namely (Johnson, 2007):

- the BSC relies on benchmarking approaches, unlike quality programs 
- the BSC integrates budgeting, resource allocation, target setting, reporting and feedback on performance into ongoing management processes,

- establishes targets for breakthrough performance (not merely best practices)

- the BSC sees strategic priorities for process enhancement.

\subsection{Customer Value Analysis and Customer Relationship Management}

Customer Value Analysis (CVA) and Customer Relationship Management (CRM) are useful tools enabling firms to improve their performance. In today's customerdriven economy, firms must adopt customer-based relationship approach. In order to develop a successful strategy for increasing customer-perceived value and market share, it is first necessary to know where a firm stands relative to its competition.

Customers have a major strategic rolein a firm and therefore, it is natural for businesses to explore ways of measuring and managing customer and other business activities directly linked to customers. Client feedback is possibly the most widely used measure of impact assessment.

The literature agrees that CVA and CRM give best results in measuring performance if used as a part of the BSC framework.

\subsection{Performance Prism}

The Performance Prism is a performance measurement framework that addresses key business issues. It is a relatively new measure developed by Cranfield School of Management in 2000. In the Performance Prism, firms view their organizations from five perspectives (rather than four of the BSC). These five perspectives include: (1) stakeholder satisfaction; (2) strategy perspective that analyses the disposable strategies that will best satisfy the stakeholders wants and needs; (3) processes perspective that looks at the processes needed in order to successfully execute chosen strategies; (4) capabilities perspective that analyses required capabilities necessary to enhance processes, and (5) stakeholder contribution perspective that defines what contributions are expected from stakeholders.

It can be said that Performance Prism is an example of customized balanced scorecard framework.

\subsection{Traditional and non-traditional performance measurement systems}

Among the above mentioned performance measurement systems today, some can be classified as traditional and others as non-traditional.

The most obvious difference among traditional and newer performance measurement models is the use of other measures besides the purely financial ones.

While, EVA and ABM use mostly financial indicators to assess the performance of a firm, they are classified as partly traditional measurement systems. BSC, different Quality programs, Performance Prism, CVA and CRM are based mostly on the non-financial measures and are classified as non-traditional performance models.

The use of the variety of measures facilitates different outputs on various aspects of business. Clearly, each of the analyzed measures uses different criteriaand has different advantages, shortcomings and outputs. Consequently, most firms use them combined in order to accurately determine its performance (table 1). 
Bilas, V. \& Franc, S.: The Role of Performance Measurement Systems on Globaliz...

\begin{tabular}{|c|c|c|c|}
\hline Model & Criteria & Output & Shortcomings \\
\hline EVA & $\begin{array}{l}\text { Accounting and other } \\
\text { financial information }\end{array}$ & $\begin{array}{l}\text { Calculation of true } \\
\text { economic profit of a firm }\end{array}$ & $\begin{array}{l}\text { Does not serve for } \\
\text { articulating a strategy of a } \\
\text { firm. Computations are } \\
\text { difficult }\end{array}$ \\
\hline $\mathrm{ABM}$ & $\begin{array}{l}\text { Accounting and other } \\
\text { financial information }\end{array}$ & $\begin{array}{l}\text { Insight into profitable and } \\
\text { profitless activities based } \\
\text { on customer or product } \\
\text { viewpoint. Information } \\
\text { about activities that } \\
\text { generate revenue in excess } \\
\text { of costs }\end{array}$ & $\begin{array}{l}\text { It may be difficult to set } \\
\text { up and establish. May } \\
\text { provide too much detail }\end{array}$ \\
\hline BSC & $\begin{array}{l}\text { Financial, customer, } \\
\text { internal business and } \\
\text { innovation and } \\
\text { learning information }\end{array}$ & $\begin{array}{l}\text { A clearly articulated } \\
\text { statement of vision and } \\
\text { strategy. A set of } \\
\text { measurable strategic } \\
\text { objectives spread over four } \\
\text { categories, each measure } \\
\text { with agreed targets. Gives a } \\
\text { set of priority "initiatives" } \\
\text { linked to the strategic } \\
\text { objectives and measures }\end{array}$ & $\begin{array}{l}\text { Not a market determined } \\
\text { performance measure, } \\
\text { may not align perfectly } \\
\text { with shareholder wealth } \\
\text { maximizing goal }\end{array}$ \\
\hline EFQM & $\begin{array}{l}\text { Leadership, policy } \\
\text { and strategy, people, } \\
\text { partnership and } \\
\text { resources, processes, } \\
\text { customer, people and } \\
\text { society results, key } \\
\text { performance } \\
\text { indicators ( KPI) }\end{array}$ & $\begin{array}{l}\text { Assessment of the quality } \\
\text { of the organizations } \\
\text { processes relative to prior } \\
\text { years. Identifies areas of } \\
\text { poor or low performance } \\
\text { against prior years }\end{array}$ & $\begin{array}{l}\text { Depends on all } \\
\text { participants' acceptance, } \\
\text { complex and abstract, } \\
\text { parameters and emphasis } \\
\text { baseless, based on self } \\
\text { assessment }\end{array}$ \\
\hline CVA/CRM & $\begin{array}{l}\text { Customer } \\
\text { information }\end{array}$ & $\begin{array}{l}\text { Insight in value equity, } \\
\text { brand equity and retention } \\
\text { equity }\end{array}$ & $\begin{array}{l}\text { Focuses only on } \\
\text { customers and fails to } \\
\text { explain and integrate } \\
\text { other non-customer } \\
\text { aspects }\end{array}$ \\
\hline $\begin{array}{l}\text { Performance } \\
\text { Prism - PP }\end{array}$ & $\begin{array}{l}\text { Stakeholder } \\
\text { satisfaction, } \\
\text { strategies, processes, } \\
\text { capabilities and } \\
\text { stakeholder } \\
\text { contribution } \\
\text { information }\end{array}$ & $\begin{array}{l}\text { A set of measurable } \\
\text { strategic objectives spread } \\
\text { over four categories: } \\
\text { stakeholder satisfaction, } \\
\text { strategies, processes, } \\
\text { capabilities and stakeholder } \\
\text { contribution }\end{array}$ & $\begin{array}{l}\text { Not dynamic in nature } \\
\text { when environment } \\
\text { changes }\end{array}$ \\
\hline
\end{tabular}

Tab. 1. Comparison of selected PMMS according to their outputs, shortcomings and criteria used

An interesting research was made by Chow and Van Der Stede (2006) in which they used survey data from manufacturing managers of 128 firms to empirically examine the extent to which firms combine financial, objective non-financial, and subjective performance measures. Results of their study are presented in the following table 2 . 


\begin{tabular}{|l|l|l|}
\hline & \multicolumn{2}{|l|}{$\begin{array}{l}\text { Emphasis on quality in } \\
\text { manufacturing }\end{array}$} \\
\hline & Low & High \\
\hline 1. Financial measures & 6 & 7 \\
\hline 2. Objective non-financial measures & 13 & 16 \\
\hline 2.1. Internal operating measures & 6 & 7 \\
\hline 2.2. Employee-oriented measures & 3 & 5 \\
\hline 2.3. Customer-oriented measures & 4 & 4 \\
\hline 3. Subjective measures & 4 & 5 \\
\hline
\end{tabular}

Tab. 2. Relative mix and uses of different measure types by firms, Chow and Van Der Stede (2006)

One third of respondent firms with the highest emphasis on quality manufacturing to the one-third of respondents with the lowest emphasis on quality were compared. The pattern that emerges from data in table 3 is that firms that place relatively greater emphasis on quality in manufacturing use more nonfinancial measures (especially ones relating to internal operations and employees) and subjective measures.

\section{Challenges of the future development of PMMS}

Concern over the development of new performance measurement systems that are in line with a complex business environment has increased. A lot of attention is given to researching the way data and information can be transformed into value-making activities. The evolution of performance measure and management systems means that firms need to create conditions for a correct and effective utilization of PMM models. Moreover, it means providing firms with IT tools needed to extract, collect and elaborate data characterising their firm (Tattiachi, Cagnazzo, Botarelli and Sameh, 2010). Moreover, without the creation of new, modern intelligent systems of controlling and accounting, performance measurement models can not evolve.

Furthermore the evolution of the PMM models requires the logic behind such models to be modified (Tattiachi, Cagnazzo, Botarelli and Sameh, 2010). That is, the primary objective of PMMS should be bridging so called "knowing-doing" gaps. Knowledge-doing gaps relate to firms' difficulties in translating information coming from the measurement processes into effective tasks.

Another challenge in the future PMMS research field is the comprehension of the cause-effect relationship the value of each indicator is based on.

\section{Conclusion}

In today's globalized markets and escalating competition, information are crucial factor of business success. These conditions make it necessary for firms to develop and adopt new intelligent systems of performance measurement. The purpose of measuring performance is not only to know how firm is performing but also to get information that will enable it to perform better. 
It can be said that the focus has changed, and nowadays more firms primarily use non-financial measures of performance combined and complemented with traditional, financial ones.

Among the vast types of models that exist today, the Balance Scorecard and Performance Prism are considered to be among the newest and most often used systems that attempt to address the shortcomings of the purely financial indicators.

Concern over the development of new performance measurement systems that are in line with a complex business environment has increased. Primary challenge is to develop such PMMS that would enable translating information coming from the measurement processes into effective tasks. Another task in the future PMMS research field is the explanation of the cause-effect relationship the value of each indicator is based on.

\section{References}

Buglione, L. \& Abram, A. (2000). Balanced scorecard and GQM: what are the differences? Software measurement conference. Available from:citeseerx.ist.psu.edu/viewdoc/download?doi=10.1.1.12.5161\&rep. Accesed on: 2010-04-10

Buiter, W. H. (2001). Globalization and regional integration; a view from Eastern Europe and the FSU. Available from: http://www.nber.org/ wbuiter/global.pdf.Accesedon: 2008-01-20

Garengo, P., Biazzo, S. \& Bitici, U.S. (2005). Performance measurement systems ain SMEs: a review for a research agenda, International Journal of Management Reviews, Vol.7, No. 1, pp.25-47

Johnson, C. (2007). Introduction to the balanced scorecard and performance measurement systems. Ch.1.. Available from: http://www.adb.org/Documents/Books/Balanced-Scorecard/default.aspAccesed on: 2010-04-10

Kaplan, R.S. \& D.P. Norton. (2001). Transforming the Balanced-Scorecard fromPerformance Measurement to Strategic Management: Part I. Accounting Horizons 15:pp.87-104

Lebas, M. (1994). Management accounting in France: Overview of past and current practice, European Accounting review, Vol. 3, No. 3, pp. 471-487

Neely, A.; Adams, C. \& Kennerly, M. (2002). The performance Prism, Prentice Hallperformance measuresManagement accounting quarterly, Vol. 7 No. 3. pp. 1-8. ISSN 1528-5359

Sanders, D. \& Hild, C. R. (2000). Six sigma on business processes: common organizationalissues, Quality Engineering. Vol.12, No.4, 603-610

Taticchi, P.; Cagnazzo, L., Botareli, M., Sameh, M. (2010). Performance measurement: Discussion of the Literature available for large companies and SMEs', Measuring business excellence, Vol. 14, No.1. pp. 4-18

Van der Stede and W. A., Chow, C. W. (2006). The use and usefulness of nonfinancial performance measures. Management accounting quarterly, Vol. 7 No. 3. pp. 1-8, ISSN 1528-5359 